\title{
STUDI KEMAMPUAN LITERASI SAINS MAHASISWA PENDIDIKAN KIMIA TERKAIT ETNOSAINS BAU NYALE
}

\section{STUDY OF SCIENCE LITERACY CAPABILITIES ON CHEMICAL EDUCATION STUDENTS RELATED TO ETNOSCIENCE BAU NYALE}

\author{
Sri Partuti Rahmayanti, Yayuk Andayani*, dan Syarifa Wahidah Al Idrus \\ Program Studi Pendidikan Kimia FKIP Universitas Mataram, Indonesia \\ *Email: yayukmtrm@gmail.com
}

Diterima: 8 Januari 2021. Disetujui: 17 Mei 2021. Dipublikasikan: 6 Juni 2021

\begin{abstract}
Abstrak: Penelitian deksriptif ex-post facto dengan pendekatan kuantitatif bertujuan untuk mendeskripsikan kemampuan literasi sains mahasiswa pendidikan kimia pada etnosains bau nyale di Universitas Mataram. Aspek literasi sains yang diukur adalah konten (pengetahuan) dengan indikator epistemic, konten dan prosedural, aspek konteks dan kompetensi (proses) dengan indikator menjelaskan fenomena secara ilmiah dan menafsirkan data dan bukti secara ilmiah. Penelitian ini melibatkan 71 mahasiswa sebagai sampel yang diperoleh melalui teknik random sampling. Data dikumpulkan menggunakan soal tes literasi sains berbasis etnosains bau nyale, selanjutnya dianalisis menggunakan statistik deskriptif. Hasilnya menunjukkan bahwa rata-rata kemampuan literasi sains mahasiswa pendidikan kimia dalam ketiga aspek termasuk dalam kategori cukup $(63,47 \%)$, sementara katagori untuk masing-masing aspek yang termasuk katagori cukup adalah aspek konten $(62 \%)$ dan aspek konteks $(65 \%)$ sedangkan aspek kompetensi termasuk katagori kurang (57\%). Hasil penelitian ini menunjukkan kemampuan literasi sain mahasiswa pendidikan kimia masih perlu ditingkatkan melalui pengenalan etnosain dalam kehidupan sehari-hari disekitar mereka.
\end{abstract}

Kata kunci: Kemampuan Literasi Sains, Nyale, Etnosains, Mahasiswa

\begin{abstract}
This ex-post facto descriptive study with a quantitative approach aims to describe the scientific literacy skills of chemistry education students on the odor of nyale ethnoscience at the University of Mataram. The aspects of scientific literacy that measured are content (knowledge) with epistemic, content, and procedural indicators, aspects of context and competence (process) with indicators of explaining phenomena scientifically, interpreting data and evidence scientifically. This study involved 71 students as a sample obtained through a random sampling technique. The data were collected using scientific literacy test questions based on nyale ethnoscience, then analyzed using descriptive statistics. The results showed that the average scientific literacy ability of chemistry education students in the three aspects was in the moderate category (63.47\%), while the categories for each aspect included in the sufficient category were the content aspect (62\%) and the context aspect (65\%). ) while the competency aspect is categorized as less (57\%). The results of this study indicate that the scientific literacy skills of chemistry education students still need to be improved through the introduction of ethnoscience in their daily lives around them.
\end{abstract}

Keywords: Scientific Literacy Skills, Nyale Ethnoscience, Student

\section{PENDAHULUAN}

Indonesia masuk dalam kategori negara berkembang dengan kualitas pendidikan yang masih rendah, dimana Indonesia berada pada peringkat 65 dari 130 negara berdasarkan data Global Human Capital Report. Hal ini dapat dilihat salah satunya dari kemampuan literasi sains peserta didik di Indonesia masih berada pada ranking 10 besar terbawah berdasarkan hasil PISA 2015. Hasil tersebut sesuai dengan hasil penelitian Adawiyah dkk [1] "Analisis Kemampuan Literasi Sains Peserta Dididk di Mataram" bahwa literasi sains peserta didik berada pada kategori sangat kurang dengan rata-rata 52,32\%. Literasi sains merupakan kemampuan masyarakat untuk menerjemahkan segala pengetahuannya untuk memecahkan masalah-masalah dalam kehidupan nyata. Faktanya, banyak fenomena dan isu dalam kehidupan masyarakat bahkan kepercayaan-kepercayaan dalam sebuah tradisi yang tidak mendapatkan penjelasan ilmiah. Hal ini mengindikasikan bahwa pengetahuan dan teknologi yang telah berkembang pesat belum mampu digunakan untuk memecahkan berbagai masalah yang timbul dalam kehidupan sehari-hari. Dewasa ini literasi sains merupakan satu dari 16 keterampilan yang harus dimiliki pada abad 21 berdasarkan analisis oleh World Economic Forum [2]. Literasi sains menjadi salah satu parameter yang sangat mempengaruhi kemajuan suatu bangsa [3].

Pentingnya literasi sains membuat beberapa organisasi pendidikan juga memiliki standar dan pedoman (benchmark) yang berkaitan dengan isi, pedagogi dan asesmen yang berliterasi sains [4]. Hal ini menunjukkan bahwa literasi sains seharusnya menjadi perhatian khusus dalam dunia 
pendidikan di Indonesia. Pembelajaran sains bukan hanya sebatas teori, namun harus mulai bermakna dalam kehidupan sehari-hari sehingga siswa tidak hanya memperoleh konsep baku tanpa mengetahui bahwa terdapat pengetahuan dan konsep yang akrab dengan lingkungan dan kehidupan sehari-hari yang dapat menumbuhkan nilai konservatif siswa [5].

Literasi sains memiliki empat aspek yang apabila dihubungkan dengan budaya lokal akan saling berkaitan. Pertama aspek konteks berupa isuisu personal, lokal dan nasional. Isu yang terjadi saat ini atau yang sudah terjadi dan membutuhkan pemahanan sains dan teknologi. Dalam hal ini isu lokal tersebut adalah budaya lokal (bau nyale). Kedua, aspek konten, berupa pemahaman faktafakta utama, konsep dan teori penjelasan yang membangun landasan ilmiah. Dalam hal ini adalah penjelasan tentang cacing laut (nyale) meliputi kandungan, morfologi dan habitat. Kandungan nyale yang diekspos dalam penelitian ini adalah kandungan protein. Ketiga aspek kompetensi, berupa kemampuan untuk menjelaskan fenomena secara ilmiah. Dalam hal ini adalah proses bau nyale, penyimpanan nyale, dan pengolahan nyale. Keempat aspek sikap, berupa minat terhadap sains, kemudian pesan moral yang terdapat dalam isu tersebut.

Kondisi Indonesia yang kaya akan budaya dan tradisi menjadi keunikan tersendiri. Ratusan ribu pulau, masing-masing memiliki budaya lokal yang beragam. Pada era globalisasi, seiring majunya ilmu pengetahuan dan teknologi, masyarakat mulai digiring berpikir maju dan mulai meninggalkan budaya-budaya leluhur tersebut karena dianggap tidak relevan dengan perkembangan zaman. Dunia pendidikan pun hanya membahas tentang sejarahsejarah budaya tersebut, tanpa mengetahui adanya kandungan sains ilmiah didalamnya. Seharusnya, pembelajaran itu dekat dengan lingkungan, memanfaatkan budaya lokal yang ada di sekitar siswa sehingga pembelajaran lebih bermakna. Seharusnya, guru lebih mengenali dan melestarikan potensi budaya lokal yang ada [6].

Pembelajaran yang dekat dengan budaya lokal disebut dengan pembelajaran berpendekatan etnosains. Etnosains adalah kegiatan mentransformasikan sains lokal atau sains yang berkembang dimasyarakat menjadi sains ilmiah yang sesuai dengan teori [7]. Langkah untuk melakukan pembelajaran berbasis etnosains adalah dengan mempelajari budaya yang dekat dengan lingkungan sekitar sehingga guru dituntut untuk menyediakan media pembelajaran berbasis etnosains tersebut. Salah satunya seperti modul berbasis etnosains yang mengangkat kebiasaan petani garam oleh Utari dkk [8] Modul tersebut bertujuan mengangkat kebiasaan petani garam yang menjadi sumber penghidupan karena garam tidak pernah lepas dari keseharian peserta didik.
Penelitian tentang pembelajaran etnosains telah dilakukan oleh beberapa peneliti, diantaranya etnosains hidrolisis garam [9] dan etnosains pengasapan ikan [10]. Berdasarkan hasil peneltian tersebut etnosains mampu meningkatkan kualitas pembelajaran bahkan mampu meningkatkan literasi sains peserta didik. Al-Fialistryani dkk [11] juga membuktikan bahwa pembelajaran inkuiri terbimbing dengan pendekatan etnosains dapat meningkatkan literasi kimia peserta didik. Hal ini sesuai dengan pendapat Sudarmin [12] dan Sujana [12] bahwa salah satu upaya untuk meningkatkan kemampuan literasi sains adalah dengan menggunakan aspek budaya lokal dalam pembelajaran.

Berdasarkan hasil wawancara dengan mahasiswa di prodi pendidikan kimia FKIP Universitas Mataram, ternyata sebagian besar mahasiswa belum mampu menjelaskan atau mendeksripsikan suatu fenomena secara ilmiah dan masih mengikuti mitos-mitos yang berkembang di masyarakat, seperti tradisi bau nyale di masyarakat Lombok. Hasil ini memberikan gambaran bahwa mahasiswa masih kesulitan untuk menghubungkan antara teori yang diperoleh dengan fenomena dalam kehidupan sehari-hari, sehingga kemampuan literasi sains mahasiswa bisa dikatakan masih kurang.

Menurut Izzatunnisa dkk [13] masih banyak peserta didik yang mengalami kesulitan dalam mengaplikasikan konsep-konsep kimia ke dalam kehidupan sehari-hari dikarenakan guru kurang melatih dan mengembangkan sains peserta didik untuk memperdalam pengetahuan mereka terkait isu-isu sains sesuai dengan tuntutan PISA, akibatnya literasi sains peserta didik menjadi rendah dan pembelajaran kimia kurang bermakna.

Berdasarkan uraian ini diketahui bahwa kemampuan literasi sains mahasiswa Pendidikan Kimia FKIP Univeristas Mataram yang terkait dengan etnosain masih rendah sehingga menarik untuk diteliti. Oleh karena itu penelitian ini bertujuan untuk mendeskripsikan kemampuan literasi sains mahasiswa pendidikan kimia pada etnosains bau nyale di Universitas Mataram

\section{METODE PENELITIAN}

Jenis penelitian deskriptif ex-post facto dengan pendekatan kuantitatif digunakan dalam penelitian ini karena variable-variable bebasnya telah terjadi ketika penelitian mulai dilakukan. Sedangkan pendekatan kuantitatif adalah informasi atau data yang diperoleh diwujudkan dalam bentuk angka [14]. Etnosain bau nyale digunakan sebagai variabel bebas dan kemampuan literasi sains mahasiswa sebagai variabel terikat.

Penelitian ini dilaksanakan pada semester III tahun ajaran 2020/2021 di FKIP Universitas Mataram dengan melibatkan 71 mahasiswa pendidikan kimia sebagai subyek penelitian. Data kemampuan literasi sains dikumpulkan 
menggunakan instrumen tes berupa soal uraian dengan total 11 pertanyaan yang telah valid dan reliabel. Pertanyaan-pertanyaan yang disajikan mencakup aspek literasi sains yaitu konten (pengetahuan), konteks dan kompetensi (proses). Data dianalisis menggunakan statistik deskriptif dan diinterpretasikan ke dalam kategori menurut Purwanto [15], seperti dalam tabel 1.

Tabel 1. Kategori Hasil Belajar Literasi Sains

\begin{tabular}{cc}
\hline Nilai & Kategori \\
\hline $86-100$ & Sangat baik \\
$76-85$ & Baik \\
$60-75$ & Cukup \\
$55-59$ & Kurang \\
$0-54$ & Sangat kurang \\
\hline
\end{tabular}

\section{HASIL DAN PEMBAHASAN}

Data kemampuan literasi sains mahasiswa ditampilan dalam bentuk data nilai tertinggi, nilai terendah, total nilai, nilai rata-rata, dan standar deviasi (Tabel-2).

Tabel 2. Kemampuan Literasi Sains

\begin{tabular}{ll}
\hline \multicolumn{1}{c}{ Komponen } & \multicolumn{1}{c}{ Hasil } \\
\hline Banyak Sampel & 71 \\
Nilai Tertinggi & 81,48 \\
Nilai Terendah & 7,40 \\
Jumlah Total Nilai & 74507,04 \\
Rata-rata \pm SD & $63,47 \pm 15,87$ \\
Katagori & Cukup \\
\hline
\end{tabular}

Berdasarkan nilai rata-ratanya diketahui bahwa kemampuan literasi sain mahasiswa masih dalam kategori cukup. Hasil ini mendukung temuan Laksono[31] bahwa kemampuan literasi mahasiswa pendidikan kimia juga dalam katagori sedang. Selanjutnya dilakukan analisis tiap aspek yaitu (a) pengetahuan (knowledge), (b) konteks (context) dan (c) kompetensi (competency).

\section{Aspek Pengetahuan}

Hasil literasi sain mahasiswa pada aspek pengetahuan ditinjau dari tiga indikator yaitu konten, procedural dan epistemik disajikan pada Gambar 1.

Soal yang dikembangkan untuk mengetahui penguasaan mahasiswa pada aspek konten merupakan pemahaman teori dan konsep yang terkait dengan materi tata nama senyawa, massa molekul relative, ikatan kimia, sifat periodic unsur dan bilangan okisdasi . Dari enam soal yang ada ( no 2a, 3a, 3b, 3c, 3d dan 4c) rata-rata nilai yang diperoleh pada indikator pengetahuan konten ini adalah $70 \%$ dengan katagori cukup.

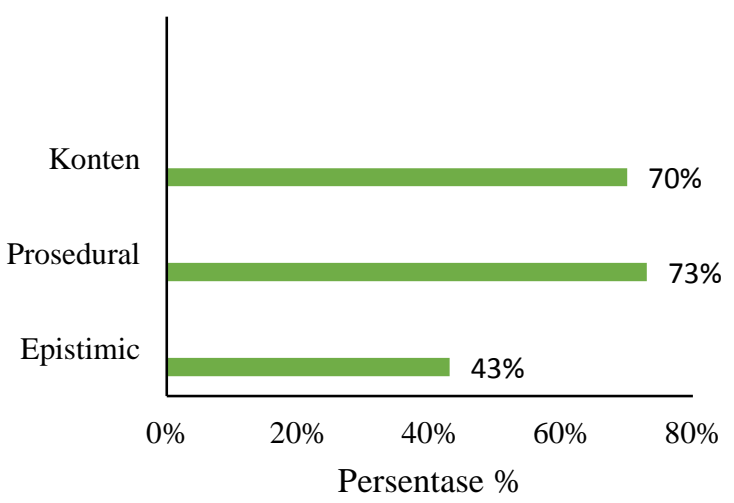

Gambar 1. Kemampuan Literasi Sains pada Aspek Pengetahuan

Aspek pengetahuan prosedural tentang pemahaman konsep untuk mendukung penyelidikan ilmiah dan pengumpulan analisis data diwakili soal nomor $2 b, 2 c$ dan $4 b$. Soal-soal ini menuntut pemahaman mahasiswa terkait kegiatan praktikum tentang protein dan faktor osmosis. Rata-rata nilai yang diperoleh pada indikator pengetahuan prosedural adalah $73 \%$ termasuk dalam katagori cukup.

Sementara pada aspek epistemik, mahasiswa dituntut untuk memahami peran suatu teori atau konsep untuk menjelaskan keutamannya dalam membangun pemahaman sains, soal yang memuat pengetahuan epistemic terdapat pada nomor 1dan 4a tentang sifat protein dan proses osmosis. Rata-rata nilai yang diperoleh pada indikator pengetahuan epistemik adalah $43 \%$ dan termasuk dalam katagori kurang.

Temuan ini menunjukkan bahwa kemampuan literasi sain mahasiswa pada aspek pengetahuan hanya dalam kategori cukup dan bahkan untuk indikator epistemik masih katagori kurang. Data ini mendukung hasil temuan Tursinawati [16], bahwa pada aspek konten mahasiswa calon guru PGSD mendapat rerata 54\% dengan katagori cukup. Sementara Marlina [17] juga menemukan bahwa kemampuan literasi sains mahasiwa mendapatkan hasil rerata $66,6 \%$ pada aspek pengetahuan konsep. Nurhidayah [18] juga membuktikan bahwa pada aspek konten mahasiswa biologi masih mendapatkan kategori cukup dengan rata-rata $71,03 \%$. Aspek pengetahuan merupakan komponen penting yang menetukan tingkat kemampuan literasi sains mahasiswa [19], sehingga kategori cukup dalam penelitian ini menunjukkan bahwa mahasiswa belum menguasai teori atau konsep kimia dasar secara utuh.

\section{Aspek Kompetensi}

Aspek kompetensi (proses) terdiri dari dua indikator yaitu : (a) menjelaskan fenomena secara ilmiah, dan (b) menafsirkan data dan bukti secara 
ilmiah. Hasil yang diperoleh disajikan dalam Gambar 2.

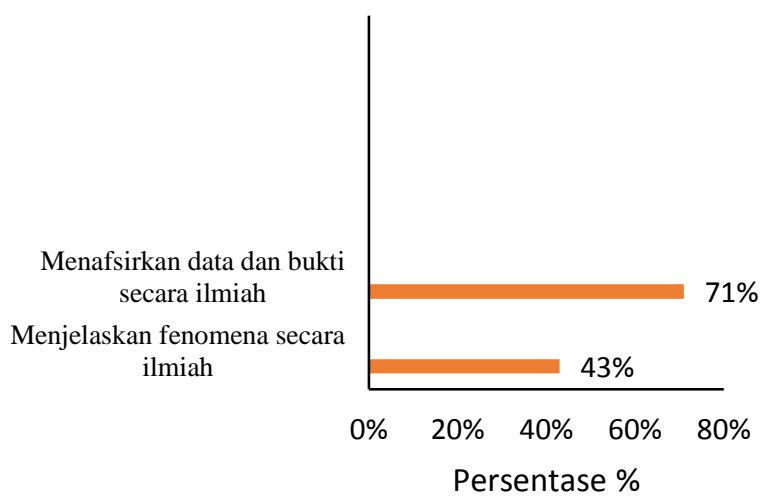

Gambar 2. Kemampuan Literasi Sains pada Aspek Kompetensi

Indikator menjelaskan fenomena secara ilmiah menuntut mahasiswa mampu mengenali dan menjelaskan masalah yang disajikan secara ilmiah, soal yang memuat indikator ini ada pada nomor 1 dan 4a. Kedua soal tersebut menuntut mahasiswa mampu menjelaskan secara ilmiah tentang kemunculan nyale, proses bau nyale dan penyimpanan nyale. Rata-rata nilai yang diperoleh pada indikator ini adalah $43 \%$ termasuk kategori kurang. Hasil serupa diungkapkan oleh Sunarti [20] bahwa kemampuan mahasiswa dalam menjelaskan fenomena secara ilmiah masih rendah karena mahasiswa kesulitan menggunakan teori yang dikuasai untuk menjelaskan berbagai keterampilan proses sains yang diperlukan dalam penyelidikan ilmiah

Indikator berikutnya dalam aspek kompetensi adalah menafsirkan data dan bukti secara ilmiah yang menuntut mahasiswa mampu menafsirkan bukti ilmiah untuk membuat kesimpulan dan mengomunikasikan, mengidentifikasi asumsi dan bukti yang mendukung kesimpulan serta menjelaskan implikasi social dari ilmu pengetahuan. Soal-soal yang memuat indikator ini adalah soal nomor $2 \mathrm{a}, 2 \mathrm{~b}, 2 \mathrm{c}, 3 \mathrm{a}, 3 \mathrm{~b}, 3 \mathrm{c}, 3 \mathrm{~d}, 4 \mathrm{~b}$ dan 4c. Pada soal-soal tersebut mahasiswa dituntut mampu menafsirkan bukti yang disajikan pada wacana soal tentang kandungan protein pada nyale dan proses pengolahannya. Rata-rata nilai yang diperoleh pada indikator menfasirkan data dan bukti secara ilmiah sebesar $71 \%$ termasuk dalam kategori cukup.

Kedua indikator pada aspek kompetensi tersebut mendapatkan rara-rata $57 \%$ termasuk dalam kategori kurang. Hasil penelitian ini mendukung temuan Yana [21] yang mendapatkan rata-rata kemampuan literasi kompetensi sebesar 59,35\% termasuk kategori kurang. Winata dkk [22] pada analisis kemampuan awal literasi sains mahasiswa pada konsep IPA juga menyimpulkan bahwa rata- rata kemampuan menjelaskan fenomena dan menfasirkan bukti secara ilmiah pada aspek kompetensi masih berada pada kategori kurang. Temuan ini menunjukkan bahwa mahasiswa masih menguasai teori hanya dengan hafalan namun belum mampu secara utuh menerapkannya dalam soal-soal analisis yang dikaitan dengan fenomena dalam kehidupan sehari-hari, sehingga gagal memberikan kesimpulan yang baik dalam menjawab soal. Hal ini sejalan dengan pendapat Mahayon [23] bahwa mahasiswa tidak mampu memberikan penjelasan terhadap langkah-langkah yang dilakukan karena lebih cenderung menggunakan hafalan dan tidak yakin dengan upaya mereka. Penegasan akan hal ini juga disampaikan oleh Sujarwanta[24] bahwa calon guru seharusnya mampu melakukan pembelajaran seperti seorang ilmuan, yaitu sistematis, teliti, dan disiplin, sehingga mampu mempelajari ilmu pengetahuan dengan keterampilan proses akan mendekatkan peserta didiknya nanti memiliki pengalaman belajar yang lengkap.

\section{Aspek Konteks}

Aspek konteks merupakan aspek yang memuat kasus atau isu relevan yang disajikan untuk. diberikan solusi menggunakan ilmu pengetahuan (teori). Data hasil tes literasi sains pada aspek konteks disajikan dalam Gambar 3.

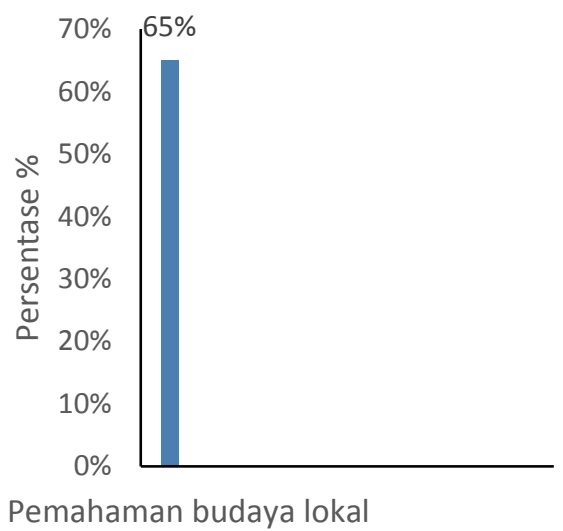

Gambar 3. Kemampuan Literasi Sains pada Aspek Konteks

Pada penelitian ini konteks yang diberikan berupa wacana terkait bau nyale. Seluruh item instrument memuat soal literasi sains mengikuti PISA 2015, dimana permasalahan berhubungan dengan diri sendiri dan lingkup komunitas (Lokal/Nasional). Soal nomor 1 memuat kemunculan dan penangkapan nyale, dimana mahasiswa diminta untuk menganalisis waktuwaktu nyale muncul ke permukaan pantai. Informasi ini berguna untuk mengetahui waktu terbaik untuk menangkap nyale dengan kualitas protein nyale yang masih baik atau belum mengalami denaturasi akibat suhu tinggi. Selain itu konteks soal lainnya pada nomor $4 \mathrm{a}$ yang memuat wacana penyimpanan 
nyale. Mahasiswa diminta menganalisis proses kimia yang terjadi pada nyale saat disimpan dalam air tawar sehingga informasi ini berguna untuk masyarakat agar tidak menyimpan nyale pada konsentrasi yang salah.

Rata-rata pencapaian pada aspek konteks adalah $65 \%$ termasuk dalam kategori cukup. Hasil ini sejalan dengan penelitian Nurhidayah [18] bahwa pada aspek konteks mahasiswa mikrobiologi mencapai hasil cukup dengan rata-rata 73,23\%. Kategori cukup menunjukkan bahwa mahasiswa sudah mampu menjawab soal-soal dalam konteks lokal/nasional dan mengenali budaya-budaya yang berkembang dalam kehidupan sekitarnya. Penelitian lain dengan hasil serupa oleh Shofiyah [25] pada tes kemampuan literasi sains mahasiswa pendidikan IPA yang berada pada kategori fungsional atau mampu menggunakan istilah ilmiah dan mendefinisikan istilah dengan benar namun hanya pada situasi tertentu dan pemahaman hanya berasal dari buku yang mereka baca saja. Selain itu Marlina [17] juga menemukan hasil penelitian bahwa penggunaan konsep atau teori secara bermakna (konteks) berada pada kategori cukup 64,4\%.

\section{Kemampuan Rata-rata Literasi Sains Mahasiswa Pnendidikan Kimia}

Berdasarkan Tabel 2 rata-rata kemampuan literasi sains mahasiswa pendidikan kimia masih berada pada kategori cukup 63,47\%. Hasil penelitian tersebut sejalan dengan penelitian Novitasari [26] bahwa skor rata-rata kemampuan literasi sains mahasiswa calon guru biologi untuk semua indikator mencapai 58,21\% yang termasuk dalam kategori cukup. Penelitian lainnya dilakukan oleh Tursinawati [16] pada mahasiwa calon guru PGSD Universitas Syiah Kuala dengan hasil ratarata $52,75 \%$ yang termasuk dalam kategori cukup. Selain itu Nurhidayah [18] juga menemukan hasil yang sama pada penelitiannya terhadap literasi sains mahasiswa FMIPA Universitas Negeri Semarang dengan rata-rata $70,25 \%$ berada pada kategori cukup. Kemudian dua penelitian yang dilakukan pada mahasiswa fisika UIN Raden Intan Lampung oleh Yana [21] mendapatkan hasil rata-rata 62,44\% dan pada mahasiswa fisika Universitas Negeri Surabaya oleh Sunarti [20] mendapatkan rata-rata $51,3 \%$, keduanya berada pada kategroi cukup.

Menurut Lestari [27] kemampuan literasi sains yang belum mencapai kategori baik dipengaruhi kurangnya kemampuan memahami konsep dan hanya memahami sebatas teori, kurangnya motivasi belajar, kemampuan aplikatif masih rendah dan kebanyakan mahasiswa hanya paham teori sebatas hafalan. Penyebab lainnya karena mahasiswa kurang mengenal dengan baik masalah yang berkembang disekitarnya dan tidak berpikir kreatif sehingga kemampuan untuk memberikan solusi masih sedang [28]. Mahasiswa juga tidak terbiasa menjawab soal-soal literasi sains yang bermuatan etnosains [25]. Menurut Sudarmin dan Sujana [12] salah satu upaya peningkatan literasi sains dilakukan menggunakan aspek budaya lokal dalam pembelajaran. Faktanya, mahasiswa tidak banyak bersentuhan langsung dengan budaya lokal yang berkembang di masyarakat yang ditunjukkan dengan hasil kemampuan literasi sains pada etnosains bau nyale masih sedang. Sedangkan di era perkembangan ilmu pengetahuan saat ini, mahasiswa tidak hanya dibutuhkan menguasai teori tetapi juga dapat mengaplikasikannya dalam kehidupan sehari-hari. Hal ini secara tidak langsung akan mempengaruhi kualitas guru di Indonesia.

Menurut Rusilowati [29] faktor yang menyebabkan kurangnya kemampuan literasi sains peserta didik di Indonesia antara lain karena guru kurang mengajarkan konsep dan mengutamakan formula ; peserta didik tidak memahami konsep dasar yang diajarkan oleh guru; peserta didik tidak memiliki pengetahuan tentang fakta-fakta, terminologi dan konsep ilmu yang cukup; keterampilan peserta didik dalam berpikir kritis, penalaran deduktif induktif, menganalisis kausalitas dan menganalisis data ilmiah yang kurang; peserta didik jarang melakukan kegiatan praktikum; peserta didik menghabiskan lebih banyak waktu dengan ilmu pengetahuan yang mempromosikan hafalan; dan kurangnya pengetahuan peserta didik dalam ilmu pengetahuan dan teknologi.

Kemampuan literasi sains guru akan berpengaruh terhadap kemampuan literasi sain peserta didiknya. Pembelajaran yang dikaitkan dengan kehidupan sehari-hari atau budaya lokal (etnosain) yang berkembang di daerah tersebut akan membuat pembelajaran lebih bermakna. Namun kenyataannya guru belum banyak yang mengimplentasikan etnosain dalam proses pembelajaran sebagaimana dilaporkan oleh Andayani dkk [30] bahwa pemahaman guru tentang perangkat dengan pendekatan etnosain sudah baik tetapi implementasinya belum optimal. Oleh karena itu mahasiswa pendidikan kimia pada semester III sebagai calon guru perlu terus meningkatkan kemampuan literasi sainsnya terutama pada pengetahuan budaya lokal setempat seperti bau nyale yang bisa diangkat dan dikonstruksi ke dalam materi kimia yang selama ini dianggap abstrak.

\section{KESIMPULAN}

Berdasarkan hasil penelitian dan pembahasan yang telah diuraikan, maka dapat disimpulkan bahwa kemampuan literasi sains mahasiswa pendidikan kimia di Universitas Mataram pada etnosains bau nyale secara keseluruhan berada pada kategori kurang dengan rata-rata 56,89. Presentase frekuensi paling tinggi pada data kemampuan literasi sains mahasiswa pendidikan kimia di Universitas Mataram pada etnosains bau nyale adalah sebesar 32,92\% dengan 
frekuensi sebanyak 37 mahasiswa dimana kategorinya termasuk cukup.

\section{DAFTAR PUSTAKA}

[1] Adawiyah, R., Andayani, Y., \& Purwoko, A, A. (2020). Analysis chemistry science literacy ability of high school student in mataram. Proceedings International Conference on Science and Technology (ICST), 1.

[2] World Economic Forum. (2015). New vision for education unlocking the potential technology. Retrived from http://www3.weforum.org/docs/WEFUSA_New VisionforEducation_Report2015.pdf

[3] Prastiwi, dkk. (2017). Studi kemampuan literasi kimia peserta didik pada materi elektrokimia. Yogyakarta: FMIPA Universitas Negeri Yogyakarta.

[4] AAAS (American Association for the Advancement of Science). (1993). Benchmarks for science literacy. New York: Oxford University Press.

[5] Fauziah, N., Andayani Y., \& Hakim, A. (2019). Meningkatkan literasi sains peserta didik melalui pembelajaran berbasis masalah berorientasi green chemistry pada materi laju reaksi. Jurnal Pijar MIPA, 14, 31-35.

[6] Wardani, S., Kadarohman, A., \& Permanasari, A. (2013). Java culture internalization in elektrometri learning based inquiry laboratory activities. Inter-Intrapersonal Intelligence, 2, 417-421.

[7] Rahayu, W., \& Sudarmin. (2015). Pengembangan modul IPA terpadu berorientasi etnosains tema energi dalam kehidupan untuk menanamkan jiwa konservasi peserta didik. Unnes Science Educational Journal, 4, 22-29.

[8] Utari, R., Andayani Y., \& Savalas, L. R. T. (2020). Pengembangan modul kimia berbasis etnosains dengan mengangkat kebiasaan petani garam. Jurnal Pijar MIPA, 15, 478-481.

[9] Arfianawati, S. (2016). Model pembelajaran kimia berbasis etnosains untuk meningkatkan kemampuan berpikir kritis siswa. Jurnal Pengajaran MIPA, 21(1), 46-51.

[10] Sapitri, R. D., Hadisaputra, S., \& Junaidi, E. (2020). Pengaruh penerapan praktikum berbasis kearifan lokal terhadap keterampilan literasi sains dan hasil belajar. Jurnal Pijar Mipa, 15(2), 122-129.

[11] Al-Fialistyani, D., Andayani, Y., Hakim, A., \& Anwar, Y. A. S. (2020). Literasi kimia pada aspek kompetensi melalui pembelajaran inkuiri terbimbing dengan pendekatan etnosains. Jurnal Pijar MIPA, 15, 537-540.

[12] Sujana, A. (2014). Pendidikan IPA teori dan praktik. Bandung: Rizqi Press.

[13] Izzatunnisa, Andayani Y., \& Hakim, A. (2019). Pengembangan LKPD berbasis pembelajaran penemuan untuk meningkatkan kemampuan literasi sains peserta didik pada materi kimia SMA. Jurnal Pijar MIPA, 14, 49-54.

[14] Sukardi. (2012). Metode penelitian pendidikan. Jakarta: Bumi Aksara.

[15] Purwanto, N. (2013). Prinsip-prinsip dan teknik evaluasi pengajaran. Bandung: Remaja Rosda Karya.

[16] Tursinawati. (2018). Pemahaman konsep literasi IPA pada mahasiswa pendidikan guru sekolah dasar. Jurnal EDUCHILD, 7.

[17] Marlina, D. (2019). Analisis kemampuan literasi sains pada mahasiswa PGSD semester 1 tahun akademik 2019/2020. Madiun: Universitas PGRI Madiun.

[18] Nurhidayah. (2020). Analisis literasi sains mahasiswa pada mata kuliah mikrobiologi di universitas negeri semarang. Semarang : UNS.

[19] Wulandari, N., \& Sholihin, H. (2016). Analisis kemampuan literasi sains pada aspek pengetahuan dan kompetensi sains siswa SMP pada materi kalor. Research Artikel Center For Science Education EDUSAINS, 8, 66-73.

[20]Sunarti, T. (2015). Pemahaman literasi sains mahasiswa calon guru fisika universitas negeri surabaya. Jurnal Pembelajaran Fisika.

[21] Yana, E. T. (2018). Skripsi analisis kemampuan literasi saintifik pada aspek kompetensi dan pengetahuan calon guru fisika pada materi gelombang dan bunyi. Lampung: Universitas Islam Negeri Raden Intan.

[22] Winata, A. Cacik, S., \& Seftria, W. R. I. (2016). Analisis kemampuan awal literasi sains mahasiswa pada konsep IPA. Education and Human Development Journal, 1.

[23] Mahayon, A. (2005). Kefahaman ungkapan algebra pelajar tingkatan empat. Tesis Sarjana, Universiti Pendidikan Sultan Idris Malaysia.

[24] Sujarwanta, A. (2012). Mengkondisikan pembelajaran IPA dengan pendekatan saintifik. Jurnal Nuansa Kependidikan, 16, 75-83.

[25] Shofiyah, N. (2015). Deskripsi literasi sains awal mahasiswa pendidikan IPA pada konsep IPA. Jurnal Pedagodia ISSN, 4, 2089 -3833.

[26] Novitasari, N. (2018). Profil kemampuan literasi sains mahasiswa calon guru biologi. Jurnal Tadris Pendidikan Biologi, 9, 36-44.

[27]Lestari, S. Puji. (2018). Analisis literasi sains mahasiswa program studi pendidikan biologi UIN raden intan lampung. Skripsi, Fakultas Tarbiyah dan Keguruan Universitas UIN Raden Intan Lampung.

[28] Islam, Zaky A., Nahadi, \& Permanasari, A. (2013). Hubungan literasi sains dan kepercayaan diri siswa pada konsep asam basa. Jurnal Penelitian dan Pembelajaran IPA, 1, 16-25.

[29] Rusilowati, A., dkk. (2016). Developing an instrument of scientific literacy assesment on the cycle them. International Journal of 
Environmental \& Science Education, 11, 57185727.

[30] Andayani, Y., Purwoko, A. A., Jamaluddin, Mahrus, M., \& Harjono, A. (2020). Identifikasi pemahaman guru tentang perangkat pembelajaran IPA SMP dengan pendekatan etnosains. Jurnal PEPADU, 1, 229-234

[31][31]Laksano, P. J. (2018). Studi kemampuan literasi kimia mahasiswa pendidikan kimia pada materi pengolahan limbah. Jurnal Pendidikan Kimia, 2, 1-12. 